\title{
CHANGES IN THE REPRESENTATION OF BUILDINGS IN DATABASES OF THE LAND AND PROPERTY REGISTER (EGIB) IN POLAND, IN 1955-2018
}

\section{Agnieszka Głowacka}

\begin{abstract}
Summary
For years, the International Federation of Surveyors (FIG) has been working on subsequent updates of guidelines for cadastral systems [Wilkowski and Rabin 2006], in order to ensure optimum management of land in the face of food shortage, urbanization and environmental degradation, as well as climate change and social conflicts [Noszczyk et al. 2017, Cegielska et al. 2018]. An initially well-developed and well-functioning cadastral system continuously evolves and transforms into an increasingly better tool for real estate management [Jones and Land 2012, Williamson and Ting 2012] while also adapting to the level of economic development of particular countries.

The article presents changes in the manner of representing buildings in the Land and Property Register (EGIB) database based on seven documents constituting the legal foundation for keeping Land and Property Register in Poland in the period of 1955-2018. The scope of the graphic part, the descriptive part including distinguishing the building status, the definitions of the contour and the built-up area, as well as attention to the types of buildings and building registration data were subjected to comparison. For the guidelines as to the building's contour included in descriptive part, the numerical image of three selected buildings for the 5 analysed time periods has been presented in order to illustrate the changes that have occurred, relating to the graphic part.
\end{abstract}

\section{Keywords}

databases • Land and Property Register • real estate cadastre

\section{Introduction}

In many countries with developed market economies, the cadastral system is considered to be the basis of State operations [Larsson 1996, Enemark 2010a, 2010b, Mika et al. 2016, Noszczyk and Hernik 2017b], whereas its value and general practicality are used in a particular way, in the management of natural resources, which is extremely valuable in present times [Enemark 2010a]. An initially well-developed and well-functioning cadastral system evolves and transforms into an increasingly better tool for real estate management over the years [Williamson and Ting 2012, Jones and Land 2012], while also adapting to the level of economic development of the state. Therefore, the Register of 
Land and Buildings, or real estate cadastre, can be seen as a key element in the aspect of economic development [Hanssen 1995, Bennett et al. 2010, Enemark 2010a, 2010b] and in terms of building appropriate relations between the citizens and the State [Williamson and Wallace 2006]. Currently, from the citizens' point of view, the following features are important: easy accessibility, universality [Noszczyk and Hernik 2017a] and comprehensiveness of information that should be provided by the cadastre [Hycner 2006]. At the same time it is important from the point of view of the State to determine the directions in which the real estate cadastre should develop, with particular focus on changes taking place globally [Land 2011]. With this in mind, the International Federation of Surveyors (FIG) has been working on new guidelines for cadastral systems for years [Wilkowski and Karabin 2006], in order to ensure optimum land management in the face of food shortages, urbanization, and environmental degradation, as well as climate change and social conflicts [Noszczyk et al. 2017, Cegielska et al. 2018].

In 1995, the FIG sent out the first questionnaire that it had developed to 31 studied jurisdictions, in order to acquire results that would allow it to determine trends in the development of real estate cadastre in these location, and subsequently, to formulate overall conclusions [Kaufmann and Steudler 1998]. In the following year, the creation of a second questionnaire was initiated, focused on cost recovery aspects and on the privatization of the cadastral systems. Both studies made it possible to draw conclusions, which served as the basis for "Cadastre 2014: A Vision for A Future Cadastral System" developed several years later, and aimed at unifying cadastral systems throughout the world [Kaufman and Steudler 1998, Wilkowski and Karabin 2006]. The study contains both an analysis of the systems functioning at that time as well as development directions and visions for the transformation of the cadastre.

In most jurisdictions, cadastral systems involved land registration and maintenance of cadastral maps and were part of the land registers [Kaufman and Steudler 1998]. The exceptions were Australia, Hong Kong, Greece, and Latvia. As part of the registration of land data, information was collected about legal titles to land, restrictions and obligations for these lands. In most of the studied jurisdictions, there were links between the maintenance of the real estate cadastre and the topographic maps, and in nine of them both were among the responsibilities of the same organization. The real estate cadastre in those years covered the entire territory of the jurisdiction, and it was all-encompassing, that is the data was systematically introduced into the system for completeness [Kaufman and Steudler 1998]. Half of the analysed jurisdictions conducted operations related to the registration of real estate data and the creation of maps within one organization derived from the public sector, while the other half separated these tasks between different units, also including those from the private sector. However, the strategic responsibility for a functioning cadastral system has always been in the hands of the public sector.

The foundation the for work on the then vision of the "Cadastre 2014" was to formulate the basic definitions of land, real estate cadastre, land registration, and land registry, as introduced by Jo Hanssen [1995].

Already at that time there were certain trends observed in the development of the cadastre, aimed primarily at improving the service of interested parties, easier access to 
data, improved up-to-dateness and system efficiency. In technical terms, attention has been paid to the obvious trend towards system automation and digitization of data, and the development of a 3D cadastre [Karabin 2013].

It is worth noting that there were no Polish subjects among the 31 respondents. 11 European countries were represented, as well as some other countries from around the world. However, a certain trend that had been observed for the cadastral systems examined by the FIG could also be observed in Poland [Dawidowicz and Źróbek 2014]. Namely, over the past sixty years, we have seen a fundamental change in the principles and scope of real estate cadastre. Presently, it is aiming at adapting to the current INSPIRE Directive, which is why a number of concepts for the creation of a multidimensional cadastre arises [Stoter and Van Oosterom 2006]. The changes taking place between 1955-2015 are part of the analyses developed by the FIG as the 2014 vision of real estate cadastre [Dawidowicz and Źróbek 2011].

In Poland, the beginnings of the present cadastral system, bearing the legal decree, are recorded in 1955. In 1969 the first regulation by the Council of Ministers of Agriculture and Municipal Economy on the registration of land and buildings was issued [MRGK regulation 1969]. These two documents initially defined the principles of creating the Land and Property Register (EGiB) in Poland as one system for the whole country. Then, in 1989, the "Geodetic and cartographic law" act was passed, which defined the recording rules much more broadly [PGiK 1989], and which for many years became the basic legal act in the field of geodesy [Buśko 2016]. The documents detailing the provisions of the PGiK act included successive regulations on the registration of lands and buildings [1996, 2001, 2013, 2015], which clearly steered the cadastral system towards the vision created by the FIG.

Digital cadastral systems have been successively introduced and modernized to ensure effective property management [Williamson and Wallace 2006]. Apart from fulfilling the function of securing real estate property rights, information on real estate values, the types of land use and the state of economic development, they also guarantee the public access to the collected data, and enable the free processing and sharing of that data [Majid and Williamson 1999]. Therefore, it is an important task is to build and maintain such cadastral systems that would be tailored primarily to the needs of the users. Often, in order to make beneficial changes, one should analyse the achievements to date, and evaluate the existing systems. Unfortunately, dynamic changes in records keeping for the large area of the whole country often affect the accuracy, therefore interpretational errors and discrepancies may occur.

This article analyses the changes introduced in subsequent legal documents (laws and regulations) in the context of registration of buildings in the official records.

\section{Materials and methods}

The practical part of the analysis was carried out on the basis of seven documents, constituting the legal basis for keeping the Land and Property Register (EGiB) in Poland in the period from 1955 to 2015 . The work focuses on the part concerning the presen- 
tation of just buildings in the cadastre. The different aspects that had been compared were then summarized in a tabular format. The table indicates what is included in the graphic and descriptive parts, whether the building status was defined, which individual elements were defined, representing detailed information about the building - that is, the building's outline and built-up area, which types of buildings were identified, and which registration data about the building was included.

In the second stage, in order to illustrate the differences in interpretation resulting from the registration entries, we presented a set of contours for three buildings, in individual years when different legal bases were in force.

\section{Results and discussion}

Table 1 presents a comparison between the evaluated aspects of land and building registry in the following time ranges (periods): 1955-1996, 1996-2001, 2001-2013, 2013-2015, and from 2015 onwards.

For each time period, the legal foundations in force were specified, which constituted the reference point for the Land and Property Register. Until 2001, the property cadastre was kept mainly based on the Geodetic and Cartographic Law of 1989, and two ministerial regulations. Since 2001, the main legal act specifying the rules for keeping records consists in regulations issued by the relevant Minister.

Based on the table, one can observe significant changes that appeared after 2001, after the entry into force of the Regulation by the Minister of Regional Development and Construction regarding the registration of land and buildings. Since that time, the graphic representation of the buildings consists in a numerical description of the contour of the building, the definition of which is included in the provisions of the Regulation. It was then that the outline of the building first appeared on the cadastral map as a rectangular projection of the external walls, rather than a very arbitrary designation of the building's location. Subsequent regulations specify more precisely what the building's outline is, in order to eliminate the arising errors in the interpretation of these provisions. The errors mainly concerned those more complex buildings, consisting of overhanging structures, elements supported on pillars, or those whose ground floor level did not represent the actual shape of the building and its range. The built-up area is directly linked to the contour of the building. Hence the need to precisely determine what the outline of the building is. The EGiB only started to record the built-up area since 2001.

Another feature that appeared in $\mathrm{EGiB}$ as a result of the clarification is the status of the building, which was introduced by the regulation of 2013 [Regulation 2013]. EGiB started recording the status of the building as per the time of entry into the register. This particular aspect is informative of the transition moment for the given building, for instance the "under construction" status indicates that the data contained in the records can change quickly and will soon require updating.

The distinction between types of buildings, marked later in the register, was introduced by the regulation of 1996, and since then it has been functioning with only minor changes. 
A substantial change with the entry into force of the regulation of 2001 [Regulation 2001] was the scope of registration data regarding the building, presented in the database. Initially, in the years 1955 to 1996, only the location, purpose, material from which the building was made, the year of completion of the construction with the description and the owner's data were recorded. Over the years, the scope of this information has been expanded and clarified, and currently the regulation lists 27 points regarding building registry data. The latest point, which was introduced in 2015 , relates to the information on the building being equipped with internal technical infrastructure adapted for high-speed Internet connections.

Based on the analysis of the table, a clear analogy to some of the changes introduced by the FIG as part of the development of the "Cadastre 2014" vision and to the result of analyses carried out in 1995 is visible. Although Poland was not among the respondents included in those studies, it is evident that the cadastre in Poland was similar, and the changes that have taken place since then are part of the trends that the FIG saw in their conclusions. Subsequent changes, up to 2001, were an extension and clarification of the guidelines, which were to give the actual shape of the maintained records, while all subsequent legal acts supplemented and provided explanations of some of the inaccuracies that since became apparent. We should add that since 2001, the EGiB database has been dynamically progressing towards the digitization of both the descriptive and graphic parts.
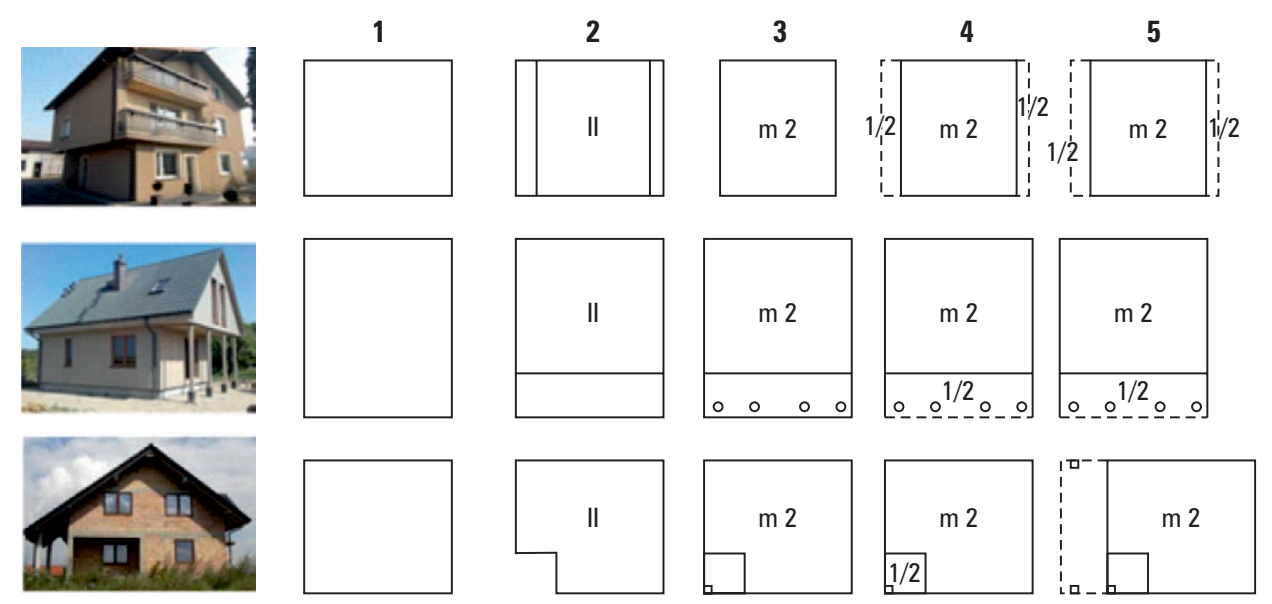

Fig. 1. Building's contour according to the guidelines implemented in the years 1) 1955-1996, 2) 1996-2001, 3) 2001-2013, 4) 2013-2015, 5) from 2015 onwards

The practical differences in the EGiB that were apparent to the recipient are best presented in Figure 1, which shows the numerical contour of three selected buildings for the 5 specified time periods. Thus, apart from the obvious differences in the descriptive part of the cadastre - resulting from, for example, differences in the data concerning the building - a more extensive file and detailed information about the building reveals differences in the presentation of buildings on the map. To a large extent, this was related 
Table 1. List of compared aspects in legal regulations for Land and Property Register records, in force between 1955 and 2015

\begin{tabular}{|c|c|c|c|c|c|}
\hline $\begin{array}{l}\text { Years/compared } \\
\text { aspects }\end{array}$ & Since 1955 & Since 1996 & Since 2001 & Since 2013 & Since 2015 \\
\hline $\begin{array}{l}\text { The legal } \\
\text { foundation, } \\
\text { introducing the } \\
\text { changes }\end{array}$ & \begin{tabular}{l|} 
The Decree of \\
February 2, 1955 \\
The Regulation by \\
the Ministers of \\
Agriculture and \\
Municipal Economy \\
of February 20, \\
1969 regarding land \\
registry
\end{tabular} & $\begin{array}{l}\text { The Regulation by the Ministers of } \\
\text { Spatial Economy and Construction, and } \\
\text { Agriculture and Food Economy, on the } \\
\text { registration of land and buildings, of } \\
\text { December 17, 1996. } \\
\text { The Act of May 17, 1989: Geodetic and } \\
\text { cartographic law }\end{array}$ & $\begin{array}{l}\text { Regulation by the Minister of Regional } \\
\text { Development and Construction, regarding } \\
\text { the registration of land and buildings of } \\
\text { March 29, } 2001\end{array}$ & $\begin{array}{l}\text { Regulation of the Minister of Administration and } \\
\text { Digitization, amending the Regulation regarding the } \\
\text { registration of land and buildings, of November } 29 \text {, } \\
2013\end{array}$ & $\begin{array}{l}\text { Regulation of the Minister of Administration and } \\
\text { Digitization, amending the Regulation regarding the } \\
\text { registration of land and buildings, of November 6, } 2015\end{array}$ \\
\hline $\begin{array}{l}\text { The graphical } \\
\text { (visual) part } \\
\text { includes }\end{array}$ & Buildings' location & $\begin{array}{l}\text { Building's situation, sequential numbers } \\
\text { of buildings, registration numbers of } \\
\text { buildings }\end{array}$ & $\begin{array}{l}\text { Numerical description of the building's } \\
\text { contour }\end{array}$ & Numerical description of the building's contour & Numerical description of the building's contour \\
\hline $\begin{array}{l}\text { The descriptive } \\
\text { part includes }\end{array}$ & $\begin{array}{l}\text { Land and building } \\
\text { survey report } \\
\text { for each unit } \\
\text { of registration } \\
\text { (consists of } \\
\text { a map, register } \\
\text { and documents } \\
\text { justifying entry into } \\
\text { the register) }\end{array}$ & $\begin{array}{l}\text { Register of buildings (for buildings that } \\
\text { are subject to ownership rights separate } \\
\text { from the land) } \\
\text { Building index (all buildings - including } \\
\text { the indication whether it is the object of } \\
\text { ownership separate from the land or part } \\
\text { thereof) } \\
\text { Land register (where you can search for } \\
\text { data describing the buildings included in } \\
\text { the real estate property) }\end{array}$ & $\begin{array}{l}\text { Register of buildings (for buildings that are } \\
\text { subject to ownership rights separate from } \\
\text { the land) } \\
\text { Building index (for buildings constituting } \\
\text { the component of land property) }\end{array}$ & $\begin{array}{l}\text { Register of buildings (for buildings that are subject to } \\
\text { ownership rights separate from the land) } \\
\text { Building index (for buildings constituting the } \\
\text { component of land property) }\end{array}$ & $\begin{array}{l}\text { Register of buildings (for buildings that are subject to } \\
\text { ownership rights separate from the land) } \\
\text { Building index (for buildings constituting the component of } \\
\text { land property) }\end{array}$ \\
\hline $\begin{array}{l}\text { The building's } \\
\text { status }\end{array}$ & NONE & NONE & NONE & $\begin{array}{l}\text { a) the construction of the building has been } \\
\text { completed (within the meaning of the provisions } \\
\text { of the Act of } 7 \text { July } 1994 \text { Construction Law) or its } \\
\text { actual use has commenced } \\
\text { b) the building is under construction } \\
\text { c) the building has been subject to demolition order } \\
\text { d) the building is subject to a building permit or } \\
\text { an application, but its construction has not } \\
\text { commenced }\end{array}$ & $\begin{array}{l}\text { a) the construction of the building has been completed } \\
\text { (within the meaning of the provisions of the Act of } \\
7 \text { July } 1994 \text { - Construction Law) or its actual use has } \\
\text { commenced } \\
\text { b) the building is under construction } \\
\text { c) the building is designated for demolition } \\
\text { d) the building is subject to a building permit or an } \\
\text { application, but its construction has not commenced }\end{array}$ \\
\hline
\end{tabular}




\begin{tabular}{|c|c|c|c|c|c|}
\hline $\begin{array}{l}\text { Years/compared } \\
\text { aspects }\end{array}$ & Since 1955 & Since 1996 & Since 2001 & Since 2013 & Since 2015 \\
\hline $\begin{array}{l}\text { The definition } \\
\text { of the building's } \\
\text { contour }\end{array}$ & $\begin{array}{l}\text { NONE (the outline } \\
\text { of the building } \\
\text { was provisionally } \\
\text { marked, or the } \\
\text { area was marked as } \\
\text { built-up area) }\end{array}$ & $\begin{array}{l}\text { NONE (the outline of the building was } \\
\text { provisionally marked, or the area was } \\
\text { marked as built-up area) }\end{array}$ & $\begin{array}{l}\text { A numerical description of the contour } \\
\text { defined by a rectangular projection on the } \\
\text { horizontal plane of the external planes of } \\
\text { external walls of the ground level of the } \\
\text { building; and in the buildings erected on } \\
\text { the pillars, of the storey supported on these } \\
\text { pillars }\end{array}$ & $\begin{array}{l}\text { 1a The contour of the building is understood as } \\
\text { a closed line defined by a rectangular projection } \\
\text { on the horizontal plane of the line of intersection } \\
\text { between the external walls of the building and the } \\
\text { land's surface } \\
\text { 1b In cases where the foundation of the building } \\
\text { intersects with the land's surface or the building is } \\
\text { set on pillars, then the contour of the building is, } \\
\text { respectively: the line designated by a rectangular } \\
\text { projection on the horizontal plane of the line } \\
\text { of intersection between the outer edges of the } \\
\text { foundation, or external edges of the pillars with the } \\
\text { surface } \\
\text { 1c In the case of buildings with only underground } \\
\text { storeys, the contour of the building is a closed } \\
\text { line designated by a rectangular projection on the } \\
\text { horizontal plane of the outer edges of that building } \\
\text { 1d If the rectangular projections on the horizontal } \\
\text { plane of the external walls of the above-ground } \\
\text { or underground storeys of the building do not } \\
\text { coincide with the contour of the building referred } \\
\text { to in paragraph } 1 \text { point } 3 \text {, or when neighbouring } \\
\text { buildings are connected by aboveground or } \\
\text { underground passages, these storeys and passages } \\
\text { are distinguished in the registry database by means } \\
\text { of a numerical description as respective blocks of } \\
\text { the building }\end{array}$ & $\begin{array}{l}\text { 1a The contour of the building is understood as a closed line } \\
\text { defined by a rectangular projection on the horizontal plane } \\
\text { of the line of intersection between the external walls of the } \\
\text { building and the land's surface } \\
\text { 1b In cases where the foundation of the building intersects with } \\
\text { the foundation wall of the building or if the building or its } \\
\text { part is set on pillars, then the contour of the building or } \\
\text { the part of that contour is, respectively the line designated } \\
\text { by a rectangular projection on the horizontal plane of the } \\
\text { lowest external edges of the walls of the level of the building } \\
\text { that are supported on these foundation walls or the pillars, } \\
\text { and in cases when it is the building's roof that is supported } \\
\text { on the pillars the outer edges of the roof } \\
\text { 1c In the case of buildings with only underground storeys, } \\
\text { the contour of the building is a closed line designated by } \\
\text { a rectangular projection on the horizontal plane of the } \\
\text { outer edges of that building } \\
\text { 1d In the case of a multi-storey building, where rectangular } \\
\text { projections on the horizontal plane of some of its storeys } \\
\text { do not coincide with the contour of the building or when } \\
\text { neighbouring buildings are connected by above-ground } \\
\text { or underground connections, those parts of storeys that } \\
\text { protrude beyond the outline of the building or constitute } \\
\text { a part or are connectors, are distinguished in the registration } \\
\text { database using a numerical description as blocks of that } \\
\text { building }\end{array}$ \\
\hline Built-up area & NONE & NONE & $\begin{array}{l}\text { The area of development (built-up area) } \\
\text { is understood as the surface area of } \\
\text { a geometric figure defined by the building's } \\
\text { contour }\end{array}$ & $\begin{array}{l}\text { The area of development (built-up area) is understood } \\
\text { as the surface area of a geometric figure defined by the } \\
\text { building's contour }\end{array}$ & $\begin{array}{l}\text { The area of development (built-up area) is understood as the } \\
\text { surface area of a geometric figure defined by the building's } \\
\text { contour, as specified in clauses la and } 1 \mathrm{~b}\end{array}$ \\
\hline Types of buildings & $\begin{array}{l}\text { NONE (only types } \\
\text { of built-up areas are } \\
\text { listed) }\end{array}$ & $\begin{array}{l}\text { 1) industry, production, energy } \\
\text { 2) transport and communication } \\
\text { 3) commerce and services } \\
\text { 4) components } \\
\text { 5) offices } \\
\text { 6) health care and social services } \\
\text { 7) residential } \\
\text { 8) education, science, culture and } \\
\text { religious worship } \\
\text { 9) production and service for } \\
\text { agriculture and farming } \\
\text { 10) other }\end{array}$ & $\begin{array}{l}\text { 1) residential buildings } \\
\text { 2) industrial buildings } \\
\text { 3) transportation and communication } \\
\text { buildings } \\
\text { 4) commercial and service buildings } \\
\text { 5) tanks, silos and storage buildings } \\
\text { 6) office buildings } \\
\text { 7) buildings of hospitals and healthcare } \\
\text { facilities } \\
\text { 8) educational, scientific and cultural } \\
\text { buildings and sports buildings } \\
\text { 9) production, services and auxiliary } \\
\text { buildings for agriculture } \\
\text { 10) other non-residential buildings }\end{array}$ & $\begin{array}{l}\text { 1) residential buildings } \\
\text { 2) industrial buildings } \\
\text { 3) transportation and communication buildings } \\
\text { 4) commercial and service buildings } \\
\text { 5) tanks, silos and storage buildings } \\
\text { 6) office buildings } \\
\text { 7) buildings of hospitals and healthcare facilities } \\
\text { 8) educational, scientific and cultural buildings and } \\
\text { sports buildings } \\
\text { 9) production, services and auxiliary buildings for } \\
\text { agriculture } \\
\text { 10) other non-residential buildings }\end{array}$ & $\begin{array}{l}\text { 1) residential buildings } \\
\text { 2) industrial buildings } \\
\text { 3) transportation and communication buildings } \\
\text { 4) commercial and service buildings } \\
\text { 5) tanks, silos and storage buildings } \\
\text { 6) office buildings } \\
\text { 7) buildings of hospitals and healthcare facilities } \\
\text { 8) educational, scientific and cultural buildings and sports } \\
\text { buildings } \\
\text { 9) production, services and auxiliary buildings for } \\
\text { agriculture } \\
\text { 10) other non-residential buildings }\end{array}$ \\
\hline
\end{tabular}




\begin{tabular}{|c|c|c|c|c|c|}
\hline $\begin{array}{l}\text { Years/compared } \\
\text { aspects }\end{array}$ & Since 1955 & Since 1996 & Since 2001 & Since 2013 & Since 2015 \\
\hline $\begin{array}{l}\text { Registration data } \\
\text { pertaining } \\
\text { to the building }\end{array}$ & $\begin{array}{l}\text { As for the buildings } \\
\text { in the descriptive } \\
\text { part of the cadastre: } \\
\text { - location } \\
- \text { designated } \\
\text { function } \\
-\quad \text { material from } \\
\text { which they were } \\
\text { made } \\
-\quad \text { year of } \\
\text { completion } \\
\text { and detailed } \\
\text { description } \\
- \text { the owner's } \\
\text { details along } \\
\text { with his place of } \\
\text { residence }\end{array}$ & $\begin{array}{l}\text { 1) date of the last data verification } \\
\text { 2) building's ID } \\
\text { 3) current number of the plot on which } \\
\text { the building is erected } \\
\text { 4) ordinal number in the address } \\
\text { directory } \\
\text { 5) number of the registration unit in the } \\
\text { land register or building register } \\
\text { 6) number and date of entry in the } \\
\text { register of monuments } \\
\text { 7) designation of the basic building } \\
\text { function according to the code list } \\
\text { 8) the value of the building, if known } \\
\text { 9) the year of completion of the } \\
\text { construction or of the last } \\
\text { modernization } \\
\text { 10) built-up area in square meters } \\
\text { 11) number of above-ground levels } \\
\text { (storeys) } \\
\text { 12) building/construction specification } \\
\text { code } \\
\text { 13) technical infrastructure specification } \\
\text { code } \\
\text { 14) number of residential units } \\
\text { 15) number of units with other purpose/ } \\
\text { function } \\
\text { 16) number of garages } \\
\text { 17) numbers of units that are the subject } \\
\text { of separate ownership within the } \\
\text { given building, along with their } \\
\text { function and usable area }\end{array}$ & $\begin{array}{l}\text { 1) building registration number } \\
\text { constituting a part of the building } \\
\text { identifier, } \\
\text { 2) ordinal number, which the building was } \\
\text { assigned in the real estate numbering } \\
\text { regulations, } \\
\text { 3) numerical description of the contour } \\
\text { defined by a rectangular projection on } \\
\text { the horizontal plane of the outer planes } \\
\text { of the external walls of the ground level } \\
\text { of the building, and in buildings erected } \\
\text { on pillars, a storey based on these pillars } \\
\text { - hereinafter the contour of the building, } \\
\text { 4) numbers of registered plots on which } \\
\text { the building is located, } \\
\text { 5) designation of the basic function of the } \\
\text { building, } \\
\text { 6) the value of the building and the date of } \\
\text { determining this value, } \\
\text { 7) year when the construction was } \\
\text { completed } \\
\text { 8) built-up area in m², } \\
\text { 9) number of above-ground levels (storeys) } \\
\text { and number of underground storeys } \\
\text { 10) information about the material from } \\
\text { which the external walls of the building } \\
\text { are built } \\
\text { 11) the quantity and assigned numbers of } \\
\text { units constituting separate premises, } \\
\text { 12) the quantity and assigned numbers of } \\
\text { premises other than those mentioned in } \\
\text { point } 11 \\
\text { 13) total usable area, expressed in } m^{2} \text {, } \\
\text { 14) the number of the register of } \\
\text { monuments maintained based on the } \\
\text { regulations on the protection of cultural } \\
\text { assets }\end{array}$ & $\begin{array}{l}\text { 1) building's ID } \\
\text { 2) building status } \\
\text { 3) numerical description of the contour } \\
\text { 4) type of building according to KŚT } \\
\text { 5) building class according to PKOB } \\
\text { 6) the main function of the building } \\
\text { 7) the value of the building, if determined } \\
\text { 8) date of construction completion, in the event of } \\
\text { reconstruction of the building } \\
\text { 9) the degree of certainty of the established dates } \\
\text { 10) information about the material from which the } \\
\text { external walls of the building are built } \\
\text { 11) information on the scope of reconstruction of the } \\
\text { building } \\
\text { 12) number of above-ground and underground levels } \\
\text { (storeys) } \\
\text { 13) built-up area } \\
\text { 14) usable area based on the measurements and } \\
\text { information contained in the construction project } \\
\text { 15) total usable area (including units constituting } \\
\text { separate property, non-separate units, and } \\
\text { appurtenant units) } \\
\text { 16) number of independent units disclosed in the } \\
\text { register } \\
\text { 17) the number in the register of monuments } \\
\text { 18) address of the building } \\
\text { 19) IDs of land plots on which the building is located } \\
\text { 20) information whether the building has been put } \\
\text { into use in whole or in part, } \\
\text { 21) designation of a part of the building put into use } \\
\text { 22) date of putting into use of the building or part of } \\
\text { the building } \\
\text { 23) number of flats according to construction } \\
\text { documentation in a residential building } \\
\text { 24) total number of rooms in a residential building } \\
\text { 25) demolition date } \\
\text { 26) the reason for the demolition of a building or } \\
\text { a part thereof }\end{array}$ & $\begin{array}{l}\text { 1) building's ID } \\
\text { 2) building status } \\
\text { 3) numerical description of the contour } \\
\text { 4) type of building according to KŚT } \\
\text { 5) building class according to PKOB } \\
\text { 6) the main function of the building } \\
\text { 7) the value of the building, if determined } \\
\text { 8) date of construction completion, in the event of } \\
\text { reconstruction of the building } \\
\text { 9) the degree of certainty of the established dates } \\
\text { 10) information about the material from which the external } \\
\text { walls of the building are built } \\
\text { 11) information on the scope of reconstruction of the } \\
\text { building } \\
\text { 12) number of above-ground and underground levels (storeys) } \\
\text { 13) built-up area } \\
\text { 14) usable area based on the measurements and information } \\
\text { contained in the construction project } \\
\text { 15) total usable area (including units constituting separate } \\
\text { property, non-separate units, and appurtenant units) } \\
\text { 16) number of independent units disclosed in the register } \\
\text { 17) the number in the register of monuments } \\
\text { 18) address of the building } \\
\text { 19) IDs of land plots on which the building is located } \\
\text { 20) information whether the building has been put into use in } \\
\text { whole or in part } \\
\text { 21) designation of a part of the building put into use } \\
\text { 22) date of putting into use of the building or part of the } \\
\text { building } \\
\text { 23) number of flats according to construction documentation } \\
\text { in a residential building } \\
\text { 24) total number of rooms in a residential building } \\
\text { 25) demolition date } \\
\text { 26) the reason for the demolition of a building or a part } \\
\text { thereof } \\
\text { 27) information on equipping the building's interior with } \\
\text { technical infrastructure suitable for high-speed Internet } \\
\text { (building adapted for high-speed Internet) }\end{array}$ \\
\hline
\end{tabular}


to a different interpretation of the records and individual elements of the building; therefore undeniably it was influenced by the human factor. As long as three-dimensional objects are presented in a two-dimensional space, we will always struggle with some difficulties. For the first building, there is the question of how to present the unsupported overhanging elements. Initially, the instructions were speaking about the contour that formed the approximate outline of the entire building. That is why the buildings were marked as simple figures. Since 2001, when the first definition of the building's outline was introduced, it has been designated as "a rectangular projection on the horizontal plane of the outer planes of external walls of the ground floor level of the building, and in buildings erected on pillars, a storey based on these pillars" [Regulation 2001].

A different way of marking functions and storeys was also introduced. In the first period, nothing was marked on the drawing, in the second period, only the Roman number of levels (storeys), while from the third period onwards, the function and the number of storeys are marked if it is greater than one, and for the sections of the building that begin only on a particular storey, these are marked as a fraction. In the years 2001-2013, the outline of the building formed a contour of the ground-level part or the elements erected on the pillars, and no overhanging elements without support were marked, as in the case of the first building featured in Figure 1. The Regulation, which entered into force in 2013, already clarified this case, but there were still significant ambiguities. In the case of the second building, we can see differences in the overhanging element. For the fourth time period, the boundary of the overhanging element was the pillars, and not the element of the building forming the overhanging part. This was specified in the regulation of 2015 , where also a point was added concerning the case where the roof is supported on the pillars, coupled with a marking on the numerical presentation of the building on the map. In the drawings, we can see how the presentation of buildings has evolved in order to best reflect the actual situation [Stoter and Van Oosterom 2006], which is why plans are currently being made to build a 3D cadastre [Van Oosterom et al. 2006], where the building will not be represented by a flat drawing thereof, but by a three-dimensional model [Karabin 2013]. This is wholly justified in the era of constantly developing $3 \mathrm{D}$ visualization technologies, and in the view of improving the operation of databases. We are moving towards the rendering of reality that is as faithful and accurate as possible, coupled with the maximum use of the capabilities of modern computer programs and equipment.

\section{Conclusions}

The analysis shows that the most important changes that took place in the format of the real estate cadastre in the aspect of buildings concern the introduction of definitions of the basic parameters, which determine the building, that is, the building's contour, built-up area, and building's status. It is worth noting that it is the outline of the building that is the key element of the building's presentation on the map, while the constant desire to render the shape of the building as faithfully as possible contributes to the emergence of newer and improved visions of the $3 \mathrm{D}$ cadastre. 
The state of cadastre in Poland until 2001 was comparable to that in other countries, and the trend of development remains in line with global trends, which results from the FIG analyses. Significant changes took place both in the aspect of the graphic representation and in the descriptive part regarding the presentation of buildings in the cadastre. The analysis shows that in recent years the changes are not so substantial any more, which may suggest the exhaustion of the possibility of presenting buildings on $2 \mathrm{D}$ maps in a more precise way than is currently used. Therefore, the development of science directs research efforts towards the transformation of a two-dimensional cadastre into a three-dimensional one. Such an approach to the database of buildings, especially in the graphic part, will make it possible to render many more details, and it will certainly help reduce the number of interpretational errors.

Researches were carried out as the part of the subject BM 2323/KGRKiF/2018

\section{References}

Bennett R., Rajabifard A., Kalantari M., Wallace J., Williamson I. 2010. Cadastral Futures: Building a New Vision for the Nature and Role of Cadastres. FIG Congress 2010. Facing the Challenges - Building the Capacity. 11-16 April 2010, Sydney, Australia.

Cegielska K., Noszczyk T., Kukulska A., Szylar M., Hernik J., Dixon-Gough R., Jombach S., Valánszki I., Filepné Kovács K. 2018. Land use and land cover changes in post-socialist countries: Some observations from Hungary and Poland, Land Use Policy, 78, 1-18.

Dawidowicz A., Źróbek R. 2011. The evolving role of Polish cadastral system in the light of the assumptions international federation of surveyors (FIG). Studia i Materiały Towarzystwa Naukowego Nieruchomości, 19, 4.

Dawidowicz A., Źróbek R. 2014. Analysis of concepts of cadastral system technological development. Conference Proceedings. 9th International Conference "Environmental Engineering", Vilnius, Lithuania.

Enemark S. 2010a. From Cadastre to Land Governance: The role of land professionals and FIG. Annual World Bank Conference on Land Policy and Administration, 26-27 April 2010, Washington D.C.

Enemark S. 2010b. The Evolving Role of Cadastral Systems in Support of Good Land Governance. Open Symposium FIG 7 Commission, 9 September 2010, Karlove Vary, Czech Republic.

FIG 1995. FIG Statement on the Cadastre, http://www.fig.net/commission7/reports/cadastre/ statement_on_cadastre.html

FIG 1999. Bathurst Declaration, http://www.fig.net/pub/figpub/pub21/figpub21.htm

Henssen J. 1995. Basic Principles of the Main Cadastral Systems in the World. In Proceedings of the One Day Seminar held during the Annual Meeting of Commission 7, Cadastre and Rural Land Management of the International Federation of Surveyors (FIG), May 16, Delft, The Netherlands.

Hycner R. 2006. The cadastre and land registry in the aspect of real estate cadaster, Proceedings of National Conference on Science and Technology on "Aspects of the real estate cadastre", 21-22 June, Educaterrra, Olsztyn, Poland.

Jones B., Land N. 2012. Cadastre 2.0. A technology vision for the cadastre of the future, Innovative Cadastre and Land Rights Management, FIG Working Week 2012 Knowing to manage the territory, protect the environment, evaluate the cultural heritage. 
Karabin M. 2013. A concept of a model approach to the 3D cadastre in Poland. Oficyna Wydawnicza Politechniki Warszawskiej, Warszawa.

Kaufmann J., Steudler D. 1998. Cadastre 2014 a vision for a future cadastral system. FIG Commission 7 Working Group (1994-1998) "Vision Cadastre".

Land N. 2011. Cadastre 2.0 - next generation of cadastre. Presentation on 3rd Cadastral Congress. November 23-25, 2011, Warsaw, Poland.

Larsson G. 1996. Land Registration and Cadastral Systems. Addison Wesley Longman, Essex, UK.

Majid S.I.A., Williamson I.P. 1999. Cadastral Systems on the World Wide Web: A Multi-Purpose Vision, Presented at AURISA 99. The 27th Annual Conference of AURISA Fairmont Resort, Blue Mountains NSW, 22-26 November 1999.

Mika M., Siajka M., Leń P., Stręk Ż. 2016. The concept of using the water cadastre databases components for the construction of multi-dimensional cadastre in Poland. Survey Review, 201-211.

Noszczyk T., Hernik J., Głowacka A., Taszakowski J. 2017. Preventing and Resolving Social Dissatisfaction in Spatial Management in Rural Areas. 16th International Scientific Conference: Engineering for Rural Development, May 24-26, 2017, Jelgava, Latvia, 1057-1063.

Noszczyk T., Hernik J. 2017a. The necessity to keep land and property registers in an active manner, Infrastruktura i Ekologia Terenów Wiejskich, I(2), 229-241.

Noszczyk T., Hernik J. 2017b. Understanding the cadastre on rural areas in Poland after the socio-political transformation, Journal of Spatial Science, 73-95.

Rozporządzenie EGiB. 2001. Rozporządzenie MRRiB z dnia 29 marca 2001 r. w sprawie ewidencji gruntów i budynków, Dz. U. z 2001 r. Nr 38, poz. 454.

Rozporządzenie EGiB. 2013. Rozporządzenie MAiC z dnia 29 listopada 2013 r. zmieniające rozporządzenie w sprawie ewidencji gruntów i budynków, Dz. U. z 2013 r., poz. 1551.

Rozporządzenie EGiB. 2015. Rozporządzenie MAiC z dnia 6 listopada 2015 r. zmieniające rozporządzenie w sprawie ewidencji gruntów i budynków, Dz. U. z 2015 r., poz. 2109.

Stoter J., Van Oosterom P. 2006. 3D cadaster in an international context. Legal, organizational, and technological aspects, CRC Press Taylor \& Francis Group.

Ustawa PGiK 1989. Ustawa z dnia 17 maja 1989 r. - Prawo geodezyjne i kartograficzne, Dz. U. z 1989 r. Nr 30, poz. 163, z późn. zm.

Wilkowski W., Karabin M. 2006. Cadastre 2020 - a Vision for a Future Cadastral System in Poland, XXIII FIG Congress 8-13 October 2006, Munich, Germany.

Williamson I., Ting L. 1999. Cadastral trends. A synthesis. The Australian Surveyor, 4, 1, 46-54.

Williamson I.P., Wallace J. 2006. Spatially enabling governments: A new direction for land administration systems. Proceedings of the XXIII FIG Congress, Shaping the Change, TS 23. Munich, Germany, October 8-13.

Van Oosterom P., Ploeger H., Stoter J., Thompson R., Lemmen C. 2006. Aspects of a 4D Cadastre: A First Exploration. Shaping the Change XXIII FIG Congress, Munich, Germany, October 8-13.

Zarządzenie Ministrów Rolnictwa i Gospodarki Komunalnej z dnia 20 lutego 1969 r. w sprawie ewidencji gruntów, M.P. 1969, Nr 11, poz. 98.

Mgr inż. Agnieszka Głowacka, doktorantka

Uniwersytet Rolniczy w Krakowie

Katedra Geodezji Rolnej, Katastru i Fotogrametrii

30-198 Kraków, ul. Balicka 253a

e-mail: a.glowacka@ur.krakow.pl

ORCID: https://orcid.org/0000-0003-2968-9537 